\title{
Development and nutritional evaluation of mango powder based instant ice cream mix in different packaging materials
}

\author{
K.P. SiVAKUMAR ${ }^{1 *}$ AND D. MALATHI ${ }^{2}$ \\ ${ }^{1}$ Krishi Vigyan Kendra (TNAU), Virinjipuram, VELLORE (T.N.) INDIA \\ ${ }^{2}$ Post Harvest Technology Centre, Tamil Nadu Agricultural University, COIMBATORE (T.N.) INDIA \\ Email : drsiva77@rediffmail.com \\ *Author for Correspondence \\ Research chronicle : Received : 29.01.2016; Revised : 18.04.2016; Accepted : 01.05.2016
}

SUMMARY :

Mango is perishable in nature with shortest shelf-life and easily damaged during post harvest handling and transportation. The Panchavarnam (Magnifera indica L.) variety of mango was selected and their pulps were dried by foam mat drying technique with the addition of foaming agents. Foaming agents such as glycerol-mono-stearate, methyl cellulose and egg albumen with different whipping time were studied to fix optimum level of foaming agent and whipping time required to prepare good quality fruit powder. Foamed mango pulp was dried at $65^{\circ} \mathrm{C}$ in a cabinet drier. The prepared mango powders were packed at different packaging materials and stored at room temperature. Instant ice cream mix was prepared from freshly processed mango powder and packed in different packaging materials showed an increase in the level of moisture, acidity and reducing sugar and decrease in $\mathrm{pH}$, total sugar and protein during the storage period. The level of TSS was unaltered in fruit powder based instant ice cream mixes during the study period. Among the packaging materials MPP was best nutritional retention compared to others during storage period.

KEY WORDS : Mango powder, Foaming agents, Ice cream mix, Nutritional composition, Packaging materials

How to cite this paper : Sivakumar, K.P. and Malathi, D. (2016). Development and nutritional evaluation of mango powder based instant ice cream mix in different packaging materials. Internat. J. Proc. \& Post Harvest Technol., 7 (1) : 53-59. DOI: 10.15740/HAS/IJPPHT/7.1/53-59 